\title{
Hepatitis B Knowledge Among Iranian Adolescents: A National Survey
}

\author{
Nader Roushan ${ }^{1, *}$, Mohsen Nasiri Toosi ${ }^{1}$, Alipasha Meysamie ${ }^{2}$, Abdoul-Reza Esteghamati ${ }^{3,4}$, \\ Homazad Hajrassuliha ${ }^{4}$ \\ ${ }^{1}$ Department of Internal Medicine, Division of Gastroenterology, Tehran University of Medical Sciences, Tehran, Iran \\ 2 Department of Preventive and Community Medicine, Tehran University of Medical Sciences, Tehran, Iran \\ ${ }^{3}$ Department of Pediatrics, Tehran University of Medical Sciences, Tehran, Iran \\ ${ }^{4}$ Center for Disease Control and Prevention of Iran, Tehran, Iran \\ ${ }^{*}$ Corresponding Author: Nader Roushan, Department of Internal Medicine, Division of Gastroenterology, Tehran University of Medical Sciences, Tehran, Iran. Tel/Fax:+98-2166939922, \\ E-mail:nroshan@tums.ac.ir.
}

Received: April 14, 2013; Accepted: August 6, 2013

\begin{abstract}
Background: Hepatitis B is the most prevalent chronic infectious liver disease worldwide with serious sequelae. Prevention of the infection can be provided by universal vaccination and improvement in knowledge and behavior about disease transmission. Provision of any educational program requires inquiry about target group baseline knowledge.

Objectives: The aim of this study was to assess Iranian adolescents' knowledge about hepatitis B (HBV) and associated factors.

Patients and Methods: We conducted a questionnaire-based national survey of 18-year-old adolescents according to stratified cluster random sampling in Iran during 2007.

Results: Response rate was 87\%. Most adolescents (60\%) knew that HBV infects the liver. Percentage of adolescents who gave correct answers to major routes of HBV transmission were as follows: spouse of an infected person $59 \%$, multi-partners $66 \%$, intravenous drug use $73 \%$, body piercing 55\% and personal belongings 55\%. Higher levels of education, living in rural areas, marriage and (except for body piercing) female gender were associated with better knowledge. The knowledge of HBV infected individuals about major routes of HBV transmission was low $(\mathrm{P}<0.001)$.

Conclusions: There are important deficits in adolescents' knowledge about HBV that requires attention of health educators to tailor educational programs for specific groups.
\end{abstract}

Keywords: Hepatitis B virus; Knowledge; Health Care Surveys; Adolescent

\section{Background}

Hepatitis B virus (HBV) infection may result in chronic liver disease, which can progress to important sequelae such as cirrhosis and hepatocellular carcinoma (HCC) (1). About $80 \%$ of HCC is etiologically related to HBV (2) and Asia is the home for $75 \%$ of all hepatitis B carriers $(3,4)$. Iran, in the Middle East, has moved from intermediate rate of HBV in the past to the current low HBV seroprevalence of $1.7 \%$ and strategies for HBV reduction is still a national public health priority (5-7). Vertical and childhood HBV transmission, once important routes of transmission in Iran (4) have decreased by widespread neonatal vaccination and screening of pregnant women in recent decades, and transmission by horizontal ways such as sexual contact and drug use, which are major ways in Western societies, have become more important (8-10).

Even though HBV infection has a lower risk of chronicity when acquired in adolescence, it is still a public health problem and 70\% of HBV infections in the United States occur in adolescents (11); once infection occurs, it can be transmitted horizontally via blood products, sexual and even household contacts. Two strategies are helpful for reducing HBV infection: first, case finding and targeted education and immunization for reducing vertical, sexual and household transmission, and second, universal vaccination and promotion of safe sex practices at a community level. After graduating from high school, adolescents may go to college or start a job; in either case, they go to a more open social circumstance and would be more exposed to HBV.

It has been shown that for many diseases, having appropriate knowledge, attitude and practice may reduce the probability of disease acquisition among at risk populations. In reality, there is little knowledge about contagious diseases $(12,13)$ and acceptance of preventive measures could be improved by educating people (14-16). There have been several studies that evaluated the HBV knowledge of Asian minorities in the US such as Vietnam-

Implication for health policy/practice/research/medical education:

Gaining better understanding of the knowledge people have about Hepatitis B, will allow improvement in educational programs and through this may prevent Hepatitis B propagation.

Copyright (C) 2013, Kowsar Corp.; Published by Kowsar Corp. This is an open-access article distributed under the terms of the Creative Commons Attribution License, which permits unrestricted use, distribution, and reproduction in any medium, provided the original work is properly cited. 
ese and Cambodians in Seattle $(2,17)$ and Vietnamese students in Massachusetts (11) and according to the findings, the knowledge of the studied subjects was mostly low. On the other hand, studies on Singaporean people showed that their knowledge was suitable $(3,18)$.

\section{Objectives}

Relatively few studies have focused on Iranian adolescents. As health education programs should be based on knowledge of the target population, we conducted a community-based survey to assess Iranian adolescents' knowledge about hepatitis B.

\section{Patients and Methods}

\subsection{Study Design}

This study was conducted during a national campaign for catch-up HBV vaccination of all 18-year-old Iranian adolescents in February 2007. The data for this study was collected using a multistage cluster sampling method from all the 30 Iranian provinces. Both rural and urban areas were included. Briefly speaking, health and medical services are provided by 41 medical sciences universities of Iran, each university in its territory has one rural health center for each village and several urban health centers for cities according to their population size. According to stratified cluster random sampling, five rural and five urban health centers were selected in each university territory; using health ministry statistics, 16,075 questionnaires were distributed among these centers proportional to their population size.

The survey was conducted by the center for disease control and prevention staff of each university in its rural and urban health centers throughout the country. The project was approved by the Research Ethics Board at the University of Tehran. To prevent any assumption of coercion, adolescents were asked to participate after being vaccinated. A brief description about the survey was given to the adolescents, after which they were invited to participate in the study. They were told that they could freely refuse to participate without any penalty. The questionnaire was self-administered and anonymous. During completion of the questionnaires, the participants were allowed to ask about the meaning of the questions, if needed. They were also convinced that their proper and correct answer to the questions is of utmost importance and may lead to highly important decisions by the health authorities that can affect their own and other people's lives. It was also explained to them that we were interested in their knowledge, and that giving a wrong answer does not affect the study process and lead to an unfavorable result.

\subsection{Questionnaire}

All items were presented in Persian and questioned about the participants' demographic information (place of residence, gender, marital status, education, and their father's, mother's and if married, spouse's education) and knowledge. One knowledge question was about the organ infected by the hepatitis B virus, 3 questions concerned squeal of the disease and 14 questions were about the risk factors for transmission. The questionnaire was first pretested by 5 adolescents of similar age to ensure understanding of all items and then completed two times with one-week intervals, by 15 adolescents to evaluate test-retest reliability $(r>0.6)$. Next, it was piloted in a class of 34 students at a high school for final revision and calculation of sample size. We tried to ask about sensitive subjects with non-offensive questions (19).

\subsection{Data Analysis}

Answers to knowledge items were dichotomized into correct answers (yes or no) versus others (incorrect answer and don't know). Proportions of respondents who correctly answered the questions were presented by percentages. Associations between demographic data and major risk factors relevant to adolescents were examined using the chi square test and logistic regression models. SPSS vs. 17.0 (SPSS Corp., Chicago, Il, USA) was used for analyses. $\mathrm{P}$ values $<0.05$ were considered significant. Odds ratios and 95\% confidence intervals were calculated for all comparisons.

\section{Results}

Response rate was $87 \%$ (13,965 questionnaires returned). More than half (57.7\%) of respondents were at their appropriate level of education, which was in the last year of high school or precollege year. Table 1 shows baseline characteristics of the study population. Regarding the education levels of the respondents' parents, only 3.1\% of their mothers and $7.8 \%$ of their fathers had college degrees, and $61.9 \%$ and $49.9 \%$ of them had elementary or lower education, respectively. Nearly two-thirds of the respondents (60.3\%) knew that HBV infects the liver. The lowest rate of awareness of the participants for HBV sequelae was about causation of cancer (38.1\%).

The majority of respondents correctly identified blood contact and intravenous drug use (IDU) as risk factors for HBV acquisition (72.8 and 70.1 percent, respectively); the lowest rate of correct answers to risk factors was for household contact (29.2\%). Table 2 shows the percentage of respondents who correctly answered the knowledge questions. Higher levels of education, living in rural areas, marriage and female gender were factors associated with better knowledge (all P values $\leq 0.03$ ); Table 3 shows differences in knowledge about major risk factors of HBV transmission according to different variables. 
Roushan $N$ et al.

Table 1. Characteristics of Study Group $(n=13,964)$

Frequency of States, \%

Gender

Male

42.5

Female

57.5

Residence

Urban

64.4

Rural

35.6

Marital status

Married

8.7

Single

91.3

Education level

Precollege

1.5

High school diploma

56.2

Middle school

37

Elementary school and lower

5.3

Mother education status

College 3.1

High school diploma $\quad 16.5$

Middle school $\quad 18.6$

Elementary school and lower $\quad 61.9$

Father education status

$\begin{array}{ll}\text { College } & 7.8 \\ \text { High school diploma } & 22.4 \\ \text { Middle school } & 20.5 \\ \text { Elementary school and lower } & 49.4\end{array}$

Spouse education status

College 11

High school diploma $\quad 39.5$

Middle school 31.3

Elementary school and lower $\quad 18.2$

Table 2. Hepatitis B Knowledge

\begin{tabular}{|c|c|c|}
\hline & Correct Answer & Percent \\
\hline Which organ is infected by Hepatitis B? ${ }^{\mathrm{a}}$ & Liver & 60.3 \\
\hline \multicolumn{3}{|l|}{ Which statement is correct about Hepatitis B? } \\
\hline Hepatitis B can be severe and fatal. ${ }^{\mathrm{b}}$ & Yes & 57 \\
\hline Hepatitis B can cause liver cancer. ${ }^{\mathrm{b}}$ & Yes & 38.1 \\
\hline Hepatitis B can persist in body lifelong. ${ }^{\text {b }}$ & Yes & 39.7 \\
\hline \multicolumn{3}{|l|}{ Who is at risk of Hepatitis $B$ ? } \\
\hline Medical personnel ${ }^{\mathrm{b}}$ & Yes & 43.3 \\
\hline Prisoners ${ }^{\mathrm{b}}$ & Yes & 59.9 \\
\hline Those who ingest opium. $^{\mathrm{C}}$ & No & 24.2 \\
\hline Those who inhale opium. ${ }^{\mathrm{C}}$ & No & 28.4 \\
\hline Those who inject drugs. ${ }^{\text {b }}$ & Yes & 72.8 \\
\hline
\end{tabular}




\begin{tabular}{|c|c|c|c|c|c|}
\hline \multicolumn{4}{|c|}{ Those who have had contact with blood of a person with Hepatitis B. ${ }^{b}$} & Yes & 70.1 \\
\hline \multicolumn{4}{|c|}{$\begin{array}{l}\text { Those who have had contact with body secretions of person with Hepatitis B } \\
\text { such as saliva } \mathrm{b}\end{array}$} & Yes & 47.6 \\
\hline \multicolumn{4}{|c|}{ Spouse of person with Hepatitis $\mathrm{B}^{\mathrm{b}}$} & Yes & 59.1 \\
\hline \multicolumn{4}{|c|}{ Those who have had a person with Hepatitis B at home (except for spouse) ${ }^{b}$} & Yes & 29.2 \\
\hline \multicolumn{4}{|c|}{ Those who have had body piercing e.g. tattoo ${ }^{b}$} & Yes & 55.3 \\
\hline \multicolumn{4}{|c|}{ Those who have had hand shaking with a person with Hepatitis $\mathrm{B}^{\mathrm{C}}$} & No & 42 \\
\hline \multicolumn{4}{|c|}{$\begin{array}{l}\text { Those who have breathed in a room where a person with Hepatitis B coughed } \\
\text { or sneezed? }^{c}\end{array}$} & No & 40.6 \\
\hline \multicolumn{4}{|c|}{$\begin{array}{l}\text { Those who have shared personal belongings with a person with Hepatitis B } \\
\text { e.g. razor (without a cut). }{ }^{\text {. }}\end{array}$} & Yes & 55.2 \\
\hline \multicolumn{4}{|c|}{ Multi-partner persons ${ }^{b}$} & Yes & 66 \\
\hline \multicolumn{6}{|c|}{$\begin{array}{l}\text { a Liver versus eye, skin, other organs..., Don't know. } \\
\text { b Yes versus No or Don't know. } \\
\text { c No versus Yes or Don't know. }\end{array}$} \\
\hline \multicolumn{6}{|c|}{$\begin{array}{l}\text { Table 3. Relationship Between Independent Variables and Knowledge About Major Risk Factors of HBV Transmission Relevant to } \\
\text { Adolescents }{ }^{\text {a }}\end{array}$} \\
\hline \multirow[t]{3}{*}{ Demographics } & \multicolumn{5}{|c|}{ Major Risk Factors for HBV Transmission } \\
\hline & \multicolumn{2}{|c|}{ Sexual Contact } & \multirow{2}{*}{$\begin{array}{l}\text { Intravenous Drug } \\
\text { Use }\end{array}$} & \multirow[t]{2}{*}{ Body Piercing } & \multirow{2}{*}{$\begin{array}{l}\text { Personal Belong- } \\
\text { ings }\end{array}$} \\
\hline & $\begin{array}{l}\text { Spouse of an In- } \\
\text { fected Person }\end{array}$ & Multi-Partnership & & & \\
\hline \multicolumn{6}{|l|}{ Gender } \\
\hline Male & $55.7^{* *}$ & $63.4^{* *}$ & $71.4^{* *}$ & 54.5 & $54.8^{* *}$ \\
\hline Female & 61.5 & 68.1 & 73.9 & 55.9 & 55.5 \\
\hline $\mathrm{OR}(95 \% \mathrm{CI})^{\mathrm{b}}$ & $1.24(1.1-1.4)$ & $1.26(1.1-1.5)$ & $1.37(1.2-1.6)$ & $0.96(0.9-1.1)$ & $0.78(0.7-0.9)$ \\
\hline \multicolumn{6}{|l|}{ Residence } \\
\hline Urban & $58.6^{*}$ & $65.6^{* *}$ & $70.8^{* *}$ & $52.4^{* *}$ & $52.3^{* *}$ \\
\hline Rural & 60.1 & 67.1 & 76.8 & 60.7 & 60.2 \\
\hline OR $(95 \% \mathrm{CI})$ & $1.14(1.0-1.3)$ & $1.5(1.3-1.8)$ & $1.4(1.3-1.6)$ & $1.4(1.2-1.6)$ & $1.25(1.1-1.4)$ \\
\hline \multicolumn{6}{|l|}{ Marital status } \\
\hline Married & $61.3^{* *}$ & $68.3^{* *}$ & $75.9^{* *}$ & $58.2^{* *}$ & $57.7^{* *}$ \\
\hline Single & 59 & 66 & 72.5 & 55.1 & 55 \\
\hline OR $(95 \% \mathrm{CI})$ & $2.1(1.7-2.5)$ & $1.2(1.0-1.4)$ & $1.16(1.0-1.3)$ & $1.5(1.2-1.8)$ & $1.2(1.1-1.4)$ \\
\hline \multicolumn{6}{|l|}{ Education } \\
\hline Precollege & $76.9^{* *}$ & $80.9^{* *}$ & $87^{* *}$ & $66.5^{*}$ & $61.1^{*}$ \\
\hline $\begin{array}{l}\text { High school } \\
\text { diploma }\end{array}$ & 61.1 & 67.9 & 73.3 & 55.6 & 54.7 \\
\hline Middle school & 56.9 & 64.4 & 72.4 & 55.1 & 56.9 \\
\hline $\begin{array}{l}\text { Elementary } \\
\text { school and } \\
\text { lower }\end{array}$ & 50 & 57.6 & 68.1 & 53.1 & 52.5 \\
\hline $\mathrm{OR}(95 \% \mathrm{CI})$ & $0.88(0.8-0.9)$ & $0.82(0.7-0.9)$ & $0.88(0.8-0.9)$ & $0.96(-)$ & $0.99(-)$ \\
\hline \multicolumn{6}{|l|}{ Mother education } \\
\hline College & $64.3^{* *}$ & $69.1^{*}$ & $72.2 *$ & $65.1^{* *}$ & 53.9 \\
\hline $\begin{array}{l}\text { High school } \\
\text { diploma }\end{array}$ & 62.9 & 69.1 & 74.5 & 59 & 56 \\
\hline Middle school & 60.4 & 67.5 & 72.7 & 53.7 & 54.8 \\
\hline
\end{tabular}


Roushan $N$ et al.

\begin{tabular}{|c|c|c|c|c|c|}
\hline $\begin{array}{l}\text { Elementary } \\
\text { school and } \\
\text { lower }\end{array}$ & 57.6 & 64.9 & 72.4 & 54 & 55.4 \\
\hline OR $(95 \% \mathrm{CI})$ & $1.1(1.0-1.2)$ & $1.1(1.0-1.2)$ & $1.1(1.0-1.1)$ & $1.14(1.1-1.2)$ & $1.0(0.97-1.1)$ \\
\hline \multicolumn{6}{|l|}{ Father education } \\
\hline College & $65.8^{* *}$ & $69.7^{*}$ & 75.3 & $63.2^{* *}$ & 55.9 \\
\hline $\begin{array}{l}\text { High school } \\
\text { diploma }\end{array}$ & 61.9 & 67.8 & 73.2 & 55.8 & 54.8 \\
\hline Middle school & 59.5 & 65.6 & 72 & 52.5 & 54.1 \\
\hline $\begin{array}{l}\text { Elementary } \\
\text { school and } \\
\text { lower }\end{array}$ & 56.6 & 65.1 & 72.4 & 54.6 & 55.8 \\
\hline OR (95\% CI) & $1.2(1.1-1.2)$ & $1.1(1.0-1.2)$ & $1.1(1.0-1.2)$ & $1.1(1.1-1.2)$ & $1.0(0.99-1.1)$ \\
\hline \multicolumn{6}{|l|}{ Spouse education } \\
\hline College & $75.6^{* *}$ & $81.9^{* *}$ & 83.6 & 68.3 & 55.1 \\
\hline $\begin{array}{l}\text { High school } \\
\text { diploma }\end{array}$ & 63.6 & 72.7 & 76.3 & 57.7 & 58.7 \\
\hline Middle school & 58.6 & 66.3 & 74.1 & 55.7 & 57.1 \\
\hline $\begin{array}{l}\text { Elementary } \\
\text { school and } \\
\text { lower }\end{array}$ & 52.7 & 56.9 & 72.1 & 58.1 & 56.9 \\
\hline $\mathrm{OR}(95 \% \mathrm{CI})$ & $1.4(1.2-1.7)$ & $1.6(1.3-2.1)$ & $1.1(0.8-1.5)$ & $1.2(0.9-1.5)$ & $0.99(0.84-1.2)$ \\
\hline
\end{tabular}

\section{Discussion}

We found that knowledge of Iranian adolescents were different from the rest of the Asian population. Since no previous study used the same questionnaire as ours, we inevitably compared our study with several of them. The number of Iranians who knew that HBV infects the liver was more than Vietnamese students (11) (60.3 vs. 23 percent) while Iranians also had greater knowledge about the statement: "infection could persist in the body lifelong" when compared to Cambodian women (2) (39.7 vs. 24 percent). But regarding carcinogenicity of $\mathrm{HBV}$, their knowledge was lower than Cambodian women (2) and Singaporean people (3) (38.1 vs. 54 and 86 percent respectively).

Sexual contacts, IDU, body piercing and personal belongings are four important risk factors relevant to adolescents. We addressed sexual contact as a risk factor by asking whether spouse of an infected person or a person with multi-partners was at risk (correct answer to these questions: 59.1 and 66 percent, respectively); although their knowledge was not so different from responses from Cambodian ( 2 ) and Vietnamese people ( 17 ) (47 and 69.5 percent, respectively), it was still low and as this is one of the important routes of HBV transmission, it requires special consideration in health education programs. As shown in Table 3, females, married people, residents of rural areas and higher educated respondents or those with higher educated mother or father were more aware of sexual contact as a risk factor.

Knowledge about the risk of IDU, an emerging problem in recent decades in Iran (20), was acceptable and comparable to that of Singaporean people (72.8 vs. 74 percent) (3). Body piercing similar to tattooing, popular nowadays, (21) carries risk of HBV infection if the needles are shared without disinfection. In a study of undergraduate students at the health campus of a US university (22), 20\% addressed hepatitis $\mathrm{B}$ as a risk of body piercing which is lower than the response rate among Iranians (55.3\%). One of the risk factors of HBV transmission that often goes unnoticed is the use of common personal belongings such as razors and nail cutters in hairdressings and manicures. Only $55.2 \%$ of adolescents were aware of this risk factor and the response rate was lower compared to that of Vietnamese people (17) and that of Chinese people in Canada (63, 68 percent for razor, respectively) (23).

The relationship between level of education and knowledge about HBV has been shown by previous studies ( 3 , 4 ). Adolescents with higher education are more likely to have heard or read about HBV in schools or through media. Another implication of this relationship may be that, further health education should be aimed at those with lower education. We found that males usually had less knowledge about major risks of HBV transmission and since a previous health survey in Iran showed ( 4,24 ) that seroprevalence of HBV was higher in males (1.9 vs. 1.5 percent in female), this group should be the focus of 
greater education. In our study 7.3\% of respondents had been tested for HBV; they probably had felt at risk of HBV, so they had gone for the test. Unfortunately, this group and HBV positive people had lower levels of knowledge about major risks of HBV transmission and this can promote further HBV propagation (Table 3). This was in contrast to findings of a study about knowledge of HBV infected people in Singapore which revealed that they had a good knowledge of HBV ( 18 ).

Regarding the ways which do not result in transmission of HBV, Iranian adolescents' knowledge about hand shaking was lower than Cambodian (2) and Vietnamese (17) people (42 vs. 69 and 75 percent, respectively) but higher than Cambodian and Vietnamese about Coughing (40.6 vs. 10 and 31 percent, respectively). Although this knowledge doesn't seem to be important, if misperception of community is not addressed, it can lead to stigmatization of HBV infected patients and may result in them hiding their disease in situations that requires clear stating of their HBV positivity such as dentistry. Our study had several limitations. Due to restrictions with questioning people's sexual activity, we couldn't inquire the pattern of sexual activity of adolescents such as the use of condoms. All data were self-reported and we couldn't validate our data about testing for HBV or HBV positivity. On the other hand, it is possible that adolescents have had difficulty in understanding the exact meaning of questions. Nevertheless, results of this study can be used for hepatitis B preventive programs by public health and medical professionals. Future studies can focus on young people's behavior, especially high-risk groups such as HBV positive people and IV drug users and also the situation of hair dressing salons.

In conclusion, our study suggests that there were several deficits in adolescents' knowledge about HBV.These deficits were more prominent among less educated people, urban inhabitant, single people and males. HBV infected people, a source of HBV propagation, had low knowledge about the routes of transmission.

\section{Acknowledgements}

There are no acknowledgments.

\section{Authors' contributions}

Design of the study: Roushan, Nasiri. Analysis of data: Meysamie. Manuscript preparation: Roushan. Critical revision: Roushan, Meysamie. Provision of patients and obtaining funding for the study and logistical support: Esteghamati, Hajrassuliha.

\section{Financial Disclosure}

There are no conflicts of Interest about all of the authors.

\section{Funding/Support}

Supported by grant \# 30318/129200 from the Health Ministry of Iran (Center for Disease Control and Prevention) and contribution \# 86- 01- 66- 5272 from the Tehran University of Medical Sciences.

\section{References}

1. Lok AS, McMahon BJ. [AASLD Practice Guidelines. Chronic hepatitis B: update of therapeutic guidelines]. Rom J Gastroenterol. 2004;13(2):150-4

2. Taylor VM, Jackson JC, Chan N, Kuniyuki A, Yasui Y. Hepatitis B knowledge and practices among Cambodian American women in Seattle, Washington. J Community Health. 2002;27(3):151-63.

3. Lu W, Mak B, Lim SG, Aung MO, Wong ML, Wai CT. Public misperceptions about transmission of hepatitis B virus in Singapore. Ann Acad Med Singapore. 2007;36(10):797-800.

4. Zali MR, Mohammad K, Farhadi A, Masjedi MR, Nowroozi AZ, Nowroozi A. Epidemiology of hepatitis B in the Islamic Republic of Iran. Eastern Mediterranean Health J.1996;2(2):290-8.

5. Massarrat Mohammad-Sadegh, Tahaghoghi-Mehrizi Susan. Iranian national health survey: a brief report. Arch Iran Med. 2002;5:73-9.

6. Jahani MR, Motevalian SA, Mahmoodi M. Hepatitis B carriers in large vehicle drivers of Iran. Vaccine. 2003;21(17-18):1948-51.

7. Javadi AA, Avijgan M, Hafizi M. Prevalence of HBV and HCV infec tions and associated risk factors in addict prisoners. Iran J Pub Health. 2006;35(4)

8. Alter MJ, Hadler SC, Margolis HS, Alexander WJ, Hu PY, Judson FN, et al. The changing epidemiology of hepatitis B in the United States. Need for alternative vaccination strategies. JAMA. 1990;263(9):1218-22.

9. Stevens CE, Beasley RP, Tsui J, Lee WC. Vertical transmission of hepatitis B antigen in Taiwan. N Engl J Med.1975;292(15):771-4

10. Coursaget P, Yvonnet B, Chotard J, Vincelot P, Sarr M, Diouf C, et al. Age- and sex-related study of hepatitis B virus chronic carrier state in infants from an endemic area (Senegal). J Med Virol. 1987;22(1):1-5.

11. Wiecha JM. Differences in knowledge of hepatitis B among Vietnamese, African-American, Hispanic, and white adolescents in Worcester, Massachusetts. Pediatrics. 1999;104(5 Pt 2):1212-6.

12. Van Herck K, Zuckerman J, Castelli F, Van Damme P, Walker E, Stef fen R, et al. Travelers' knowledge, attitudes, and practices on prevention of infectious diseases: results from a pilot study. J Travel Med. 2003;10(2):75-8

13. Hamer DH, Connor BA. Travel health knowledge, attitudes and practices among United States travelers. J Travel Med. 2004;11(1):23-6.

14. Samoff E, Dunn A, VanDevanter N, Blank S, Weisfuse IB. Predictors of acceptance of hepatitis B vaccination in an urban sexually transmitted diseases clinic. Sex Transm Dis. 2004;31(7):415-20.

15. Rhodes SD, DiClemente RJ, Yee LJ, Hergenrather KC. Correlates of hepatitis B vaccination in a high-risk population: an Internet sample. Am J Med. 2001;110(8):628-32.

16. Short MB, Rupp R, Stanberry LR, Rosenthal SL. Parental acceptance of adolescent vaccines within school-based health centres. Herpes. 2005;12(1):23-7.

17. Taylor VM, Choe JH, Yasui Y, Li L, Burke N, Jackson JC. Hepatitis $\mathrm{B}$ awareness, testing, and knowledge among Vietnamese American men and women. J Community Health. 2005;30(6):477-90.

18. Wai CT, Mak B, Chua W, Tan MH, Ng S, Cheok A, et al. Misperceptions among patients with chronic hepatitis B in Singapore. World J Gastroenterol. 2005;11(32):5002-5.

19. Fenton KA, Johnson AM, McManus S, Erens B. Measuring sexual behaviour: methodological challenges in survey research. Sex Transm Infect. 2001;77(2):84-92.

20. Ghanbari MG, Esmaeelzade EM editors. . The role of IV drug users control in prevention of AIDS [abstract]. International Conference of AIDS.; 2004. p. C10258.

21. Larkin BG. The ins and outs of body piercing. AORN J. 2004;79(2):333-42.

22. Schorzman CM, Gold MA, Downs JS, Murray PJ. Body art: attitudes 


\section{Roushan $N$ et al.}

and practices regarding body piercing among urban undergraduates. J Am Osteopath Assoc. 2007;107(10):432-8.

23. Hislop TG, Teh C, Low A, Li L, Tu SP, Yasui Y, et al. Hepatitis B knowledge, testing and vaccination levels in Chinese immigrants to
British Columbia, Canada. Can J Public Health. 2007;98(2):125-9.

24. Sali Shahnaz, Bashtar Reza, Alavian SeyedMoayed. Risk factors in chronic hepatitis B infection: a case-control study. Hepat Mon. 2005;5(4):109. 